\title{
MJN QUALITY OF LIFE AFTER REMARRIAGE IN OLD AGE
}

\author{
Abdullah Junior S. Mangarun \\ Faculty of Nursing, Mindanao State University-Iligan Institite of Technology, Iligan City, Philippines \\ *Corresponding Author's Email: abdullahjr.mangarun@g.msuiit.edu.ph
}

\begin{abstract}
To better understand the life of the couple after remarriage by exploring their experiences including doubts, fears, apprehensions, and satisfaction of their decision to remarry. It also explored similarities and differences compared to the first marriage. The study made use of case study, a qualitative research design. Data collection was carried out for five months from February 2017 to June 2017 from the different Barangays of Iligan City, Philippines. A total of three cases were explored through a one-on-one interview which lasted for 30-45 minutes per session. Inclusion criteria include being 60 years old and above and must be remarried after the death of the previous spouse. Self-made open-ended questions focused on life after remarriage were raised during the interview. Using qualitative thematic analysis, the three important themes that emerged from the study are the following: that remarriage can bring about (1) remarriage brings forth new found happiness, (2) effective marital performance leads to contentment in remarriage, (3) remarriage brings a lifetime companionship, (4) aging gracefully. It was found out that it is still possible to find fulfillment and better quality of life after remarriage in old age.
\end{abstract}

Remarriage; Widowhood; Old age; Graceful aging; Quality oflife

\section{INTRODUCTION}

Marriage and remarriage have been shown to have a significant benefit on the mental health of the individual (Kiecot-Glaser \& Newton, 2011). Remarriage is considered to be one of the significant factors of the economic and physical well-being of the widowed (Smith, Zick, \& Duncan, 1991). Remarriage in widowhood generally arises at later ages, difficulties of incorporating a new partner into existing familial and kinship networks may outweigh the benefits a new partner bestows (James \& Shafer, 2012). The involuntary split due to the death of their partner may take much longer to recover from, leading to delays in remarriage (Amato, 2010; James \& Shafer, 2012). Hence, the concerns about childbearing will less likely impinge the widowed individuals (James \& Shafer, 2012). At present, remarriage among elderlies has been among the least researched and least known alternatives in old age (Vinick, 1978).

The death of a loved one brings changes to the individual especially in terms of emotional, physical, financial, social support aspect of life. Widowed persons may suffer more health disadvantages because of having poor relationship quality, which is a wellknown determinant of adverse health outcome (Bradbury et al., 2000; \& Umberson et al., 2006). The unmarried widows may display symptoms that are indicative of depression, such as unable to sleep at night, tearfulness, sadness, and loss of appetite and decreased body weight. Both men and women may manifest similar emotional problems after the loss of a partner. The negative effect of the death of a spouse decreases as time progresses (Smith, 1991). Then, time will come for an opportunity to remarry of which the study of Smith \& colleagues (1991) suggests that age and time have the strongest and most consistent influence on remarriage after widowhood (Robinmd, 2012).

Symptoms of depression are lower to remarried widowed than those who stayed single. It is also lowered to remarried men than in women (DeeJong-Gierveld \& Peeters, 2003). Remarriage can decrease but not totally eliminate the negative effect towards the health of the disruption marital status. Those who have been widowed and then remarried have worse health issues that those who have continuously married. Increased risk of chronic conditions and mobility limitations may 
also be triggered by marital disruption (Hughes \& Whites, 2009).

This present theory on remarriage assumes that remarriage can bring about positive effects in the lives of the new couple. It can give a new sense of security both in the financial and emotional aspects and can enhance the physical health of an individual. Moreover, successfully remarried life can be achieved when there is an approval from both children and relatives. Research revealed that children can play a key role in whether remarriage lasts, in some cases making it more challenging (Sutherland, 2014). A study reported that children of widowed individuals are typically older. They usually have a family of their own which is typically no longer living with their parents (James \& Shafer, 2012). Also, in older adults, there is an extra vulnerability of widowed to remarry due to disparities in health brought by aging. The older adults are less likely to be physically active (a) they lead a sedentary lifestyle and (b) demands caring for being less fit and potentially impaired (Pettee et al., 2006). On the other hand, one of the biggest issues elderly people face during remarriage is the discouragement of family and friends (Lamatina, 2009).

Remarriage in old age can also dispel loneliness, having found a new companion/partner in life. It is assumed that effective role performance by both partners improves the satisfaction of being remarried.

\section{Objective of the Study}

To better understand the life of the couple after remarriage by exploring their experiences including doubts, fears, apprehensions, and satisfaction of their decision to remarry. It also explored similarities and differences compared to the first marriage.

\section{METHODOLOGY}

The study followed a qualitative research design, more specifically, case study to have a better understanding of the life of the old couple after remarriage. Case studies are a detailed report of an event, group, person, and/or community being studied. Informations were collected using different methods from different of sources. The case study can be used to make new concepts (McLeod, 2008).

The study was conducted in Iligan City, Philippines where all of the informants reside. The area during the interview was based on the informant's preference.

Informed consent was secured before the conducting the study with the participants. They were informed that they can withdraw or refuse to continue or be among the study informants.

All interviews were audio-recorded and approximately lasted 30 minutes.Per confidentiality protocol, all of the information at the time of the interview was kept safe and informants were given the opportunity to ask questions or clarifications.

Thematic analysis was used to recognize the meaning among the patterns of the experiences among remarried elderly widow and widowers. Patterns are being identified through rigorous data processing, coding of data, and an unraveling of themes. Thematic analysis was used to validate the process based on the transcripts taken from the subjective answers of the respondents to the given questions in during the interview series.

The investigator ensured the protection of the ethical right of the study informants and that no ethical transgressions were committed in the conduct of the study. This study was approved by College Research, Ethics and Extension Committee (CREEC) of MSUIIT, College of Nursing.

\section{RESULTS}

The study utilized purposive sampling wherein key informants are selected based on criteria necessary to answer the objectives of the study: (1) He/ she should be at least 60 years of age. (2) Must be remarried after the death of the previous spouse. A total of three individuals were interviewed using self-made open-ended questions. The interview guide was used to facilitate logical flow in the conversation between the investigator and key informants. The key informants' profile is reflected in Table 1.

\section{Table 1: Profile of Key Informants}

\begin{tabular}{|l|c|c|c|c|c|}
\hline $\begin{array}{l}\text { Informants' } \\
\text { Pseudo names }\end{array}$ & Age & Gender & $\begin{array}{c}\text { No. of } \\
\text { Children }\end{array}$ & $\begin{array}{c}\text { No. Years } \\
\text { Widowed }\end{array}$ & $\begin{array}{c}\text { No. Years } \\
\text { Remarried }\end{array}$ \\
\hline Ner & 60 & Female & 4 & 11 & 17 \\
\hline Cab & 64 & Male & 3 & 2 & 4 \\
\hline Cam & 69 & Female & 6 & 19 & 4 \\
\hline
\end{tabular}

\section{Case Profile of the Participants}

The following cases had shown the case profile of the informants

\section{Case No. 1: A Happy Widow}

This is the case of Ner (not her real name), 60 years old, who got married at an early age of 18 and became a 
widow at 33. In their 17 years of being married, they were blessed with three children but, as a wife, Ner felt that she was taken for granted at times.

After the death of her husband due to cancer, Ner devoted her time and effort to raising her children. She recalled that as a single parent it was difficult. She was always worried about how to sustain her children's education and their daily needs. Those times were extra difficult because she was doing it alone even though she has a job as a liaison officer. Ner just prayed to God for strength and the ability to overcome every challenge in life.

Then a new love came along in the person of Luke (not his real name) - a teacher and widower with two children. At first, Ner admitted that it never crossed her mind to marry again but if God will give her a partner once again, she confessed that she will willingly accept if that person can help her improve her condition in life. The courtship lasted long (11 years to be exact) because she wanted to make sure that his intentions were pure and that he will love her children as well just like his very own.

Ner never regretted being married again in the year 2000 with the blessing of her three children who were all professionals at that time. Although, Ner's relatives did not approve their marriage at first but, Luke proved his sincerity and eventually gained their approval. Aside from her love for Luke, her reason for remarrying was to have a partner/companion to support her in providing the needs of her children. At first, she did not want to rely too much on Luke but he willingly gives and helps her financially even before they got married. He also helps her making major decisions in life.

From the start of their marriage until now, Ner can say that she is happy because she feels Luke's love for her and for her children. In the same way, Ner also shows her love for Luke by loving his two children as well. Ner said that Luke's children considered her as their second mother and they even help prepare every time she will celebrate her birthday. In the same way, Ner considered Luke's children as her very own and was happy when Luke's children converted to her religion being a born-again Christian.

Comparing her relationship now from the previous one, Ner confessed that it is better now because her first marriage was problematic and that his first husband had many vices that she did not like. Likewise, Luke's first marriage was also problematic that is why if they have conflicts, they always sort it out as soon as possible as not to create trouble in a long run. At present, Ner is proud of her relationship with Luke because she knows how to approach him if he has problems and vice versa. Ner cannot recall any major problems or conflicts that they had in the 17 years of their marriage.

Ner believed that her second marriage is a success and even though her husband is now suffering from stroke, she will continue to love and care for him because Luke has been a wonderful husband and a great provider for the family.

\section{Case No. 2: A Contented Widower}

This is the case of $\mathrm{Cab}$ (not his real name), 64 years old, Catholic, a carpenter with four children. His first marriage lasted for 19 years after his first wife died of natural death in 2011. Cab admitted that life without his wife was very lonely because he has no one to talk to and share all his problems. He felt left out and alone most of the time especially when all his four children will leave the house to go to their respective jobs. More so when he experienced sickness and bodily pain because none can compare to the touch and care of a wife. This is the main reason why $\mathrm{Cab}$ decided to look for a new wife.

$\mathrm{Cab}$ found a new love in Edna (not her real name), who happens to be a widow with seven children. He described Edna as someone who is very kind, industrious and loving. Cab admitted that he first made sure that Edna's children will like him, so he befriended them first before officially courting her. When all is well between the two families and all their children gave their consent, Cab and Edna got married in 2013. They became one big happy family.

Cab confessed that life with Edna made him happy because once again he had someone to share his daily stories and someone who will listen to his problems. Edna also took care of him every time he got sick and massage him when he felt body aches. Cab also praised Edna for doing all the household chores - cooking, laundry and cleaning the house. Unlike his first wife, whom he used to serve, Edna was the one serving him this time. He recalled how Edna would want him to just relax after he arrived home from work. Edna also is a good influence on him because he lessens his vices because of her.

There was only little adjustment when they got married because according to Cab, Edna is a submissive wife and they easily get along when they make any decisions. They agree with almost everything but every 
time they have conflicts, they sort it out immediately because they wanted to be a good example to their children.

At present, Cab is very much grateful to God for having Edna in his life. His second marriage brought the sunshine in his life because with Edna by his side he feels so loved and taken care of.

\section{Case No. 3: A Precious Widow}

This is the case of Cam (not her real name), 69 years old, a janitress with five children. Cam was already 27 years old when she got married for the first time. Her first husband had been good to her and a good provider to the needs of the family until cancer took his life in 1994. Cam's 20 years of happy marriage ended and told herself that she will never love again. Cam devoted herself to raising her five children and was able to provide for their needs and education.

Cam adjusted to a life without a partner. She figured out how to deal with loneliness and although she missed having someone to talk to and share her problems, she never entertained being married again. Until Pablo (not his real name), a businessman, came along when she was already in her senior year. At first, she was not comfortable having a suitor in her 60's so every time Pablo would visit, she would hide and tell her children to tell Pablo that she is not at home. Pablo on the other hand, became even more persistent to win her heart. He befriended her children and grandchildren until one day, one of Cam's daughter told her to give Pablo a chance.

When Cam asked Pablo why he would pursue her, Pablo just said, "I want to have a companion and serve you." To make their relationship legal in the eyes of God and man. Cam and Pablo got married in 2013 and Cam ended her being a widow for 19 years. Since both of their children approved of their marriage, Cam and Pablo found a new loving family in each other.

Cam confessed that there is not much difference in her first and second marriage. She has been blessed with a loving and supportive husband from both her first and second marriage. In their four years of being married, Cam said it has been smooth sailing so far because they both knew how to adjust to each other. She added that Pablo helped her a lot in decision making. In their spare time, they still go out together and just enjoy each other's company. Cam's advice for those who wanted to remarry to select the best. Someone who can support you and help you in times of need.

\section{Generated Themes}

Theme 1. Remarriage Brings Forth Newfound Happiness

One common answer from the three participants which they commonly felt during widowhood is loneliness. The loss of the previous spouse is tantamount to losing a partner in doing household chores, rearing children, managing finances, and expressing intimacies. Marriage is one of the most lifechanging events in every person that gives ultimate happiness. The loss of the previous spouse is detrimental and brings sadness to the widow which can be resolved by remarriage.

The coming of the new spouse brings the person back the same experience as she or he got when married with the previous spouse. The excitement and the anticipation of being with someone new make them happy. Life after widowhood with remarriage brings comfort to the widow or widower. During widowhood, children seemed to be the source of happiness among the widows and widower. But in remarriage, the love and care from the new spouse give another form of happiness. The happiness they got from the new spouse is beyond comparison to what their children can give. The happiness they get by doing things with a partner, sharing ideas with somebody with and going some places together are attributed to having a newfound partner after widowhood.

Theme 2. Effective Marital Role Leads to Contentment in Remarriage

The success of remarriage among elderlies does not only rely on exchanging vows. One must know his role as a partner. The transition from being a widow or widower to remarried couple entails effective coping and favorable adjustments to a role. The marital role involves providing the needs of the new spouse. The remarried elderly widows need to watched over by their new spouse. It is observed that the coming of the new spouse is distinctive. With aging and role performance, the outlook of the elderlies seemed different to remarriage on other life stages. In elderlies and aging, the remarried widows become less involved with their bad habits and vices. They also become so concern with the discomforts and illnesses experienced by their new spouse especially those relevant to aging. Unlike being unmarried, there is nobody who can take good care of them when they feel sick and in pain.

Similar to anybody getting married, the remarried 
elderlies view their marital relationship to last. Their marital role and newfound relationship become more meaningful as the elderlies become intuitive to the concerns and feelings of their new spouse. They gain a mutual understanding where both of them obeys one's request and patient enough to understand individual differences. The marital role also encompasses their parental role of securing the needs of each other's' children. They both become role models to their two sets of children. They become bi-parents.

Theme 3. Remarriage Promotes a Lifetime Companionship

One of the biggest rewards of getting remarried is finding a companion. Similar to the first theme, having a newfound companion brings happiness. But what is distinctive in the third theme is the meaning of refuge. Life is not always filled with happiness. Life has both its ups and downs.

Being with a companion is gaining refuge with whom you can lean on. This is totally different when they are widows. The refuges secure the elderlies that somebody is there to understand their physical and psychosocial concerns. There is somebody who can give them massage when they have sprains or even fatigue. The refuge can also act as a counselor who listens to their issues and problems. Unlike the young adults, the older adults can give a more satisfying advice since these are more meaningful and experiential-based.

\section{Theme 4: Aging Gracefully}

The experience of being with someone as the person ages makes aging more secured. Aging gracefully is the last theme which refers to the gratifying emotional experience of a person who experiences physiological changes brought by degeneration.

Everything degenerates and humans will end up aging until death. One of the unique experiences of remarrying among elderly widows is the satisfaction that they get because of the decision to be with a new spouse. They feel like they view life in a better and positive experience compared to their previous status as a widow. One of the participants claimed that her decision to remarry his new spouse is successful and despite the degenerations and disease which they soon get, they still feel gracefully blissful.

\section{CONCLUSION}

In conclusion, it is the happiness that they gain out of having a new partner in their journey of aging that makes their new chapter in life as graceful. It is not the physiological changes of aging that determines the gracefulness, rather the security and refuge that they get after the loss of their first spouse that matters most. Consequently, most of the aspects of the lives of the remarried widows come into place or resolved compared to the widowhood stage. They perceived the quality of life as better based on the satisfaction in terms of being secured by having a new partner around. The apprehensions, fears, and doubts about the decision to marry in old age were resolved with the approval of their children.

Based on the cited cases, there were no regrets on the part of the couple rather they found themselves happier and with new sense of purpose with the new partner.

Therefore, successful marriage in old age is possible when both are ready to take on new responsibilities. There is fulfillment for a better quality of life in old age when both knew how to give and take in a relationship.

\section{Recommendation}

Based on the findings and conclusion, this research recommends a better understanding among the family members of the remarried couples which have experienced the loss of the previous spouse. The phenomena and theory formulated in the study can be further explored by future researchers using more varied cases and the use of case-cross analysis. The inputs that this theory elaborates can be used as a basis for health care practitioners in getting a better understanding of family dynamics especially recently that the definition and composition of the family have been changing constantly.

\section{Conflict of Interests}

The authors declare that they have no conflict of interest.

\section{ACKNOWLEDGEMENT}

The authors are thankful to the institutional authority for completion of the work. 


\section{REFERENCES}

Amato, P.R. (2010). Research on Divorce: Continuing Trends and New Developments. Journal of Marriage and Family, 72(3), pp 650-666.

Bradbury T.N., Fincham F.D. \& Breach S.R.H. (2000). Research on the nature and determinants of marital satisfaction: A decade in review. Journal of Marriage and the Family, 62(4), pp 964-980. 10.1111/j.1741-3737.2000.00964.x

Dee Jong Gierveld, J. \& Peeters, A. (2003). The Interweaving of Repartnered Older Adults' Lives with Their Children and Siblings. Ageing \& Society, 23(02), pp 187-205.

Hughes, M.E. \& Waite, L.J. (2009). Marital Biography and Health at Mid-Life. Journal of Health and Social Behavior, 50(3), pp $344-358$.

James, S.L. \& Shafer, K. (2012). Temporal differences in remarriage timing: Comparing divorce and widowhood. Journal of Divorce \& Remarriage, 53(7), pp 543-558.

Kiecolt-Glaser, J. K. \& Newton, T. L. (2001). Marriage and health: his and hers. Psychological Bulletin, 127(4), pp 472503.

Lamatina, M. (2009). Marriage \& Remarriage. NAP411 Navigating the aging Process, Senior Information and Directory. Retrieved from https://www.nap411.com/family/family-diversity/marriage-a-remarriage

McLeod, S.A. (2008). Case study method. Simply psychology, pp.1-3. Retrieved from http://www. simplypsychology. org/case-study.html

Pettee, K., Brach, J., Kriska, A., Boudreau, R., Richardson, C., Colbert, L., Satterfield, S., Visser, M., Harris, T., Ayonayon, H. \& Newman, A., (2006). Influence of marital status on physical activity levels among older adults. Medicine \& Science in Sports \& Exercise, 38(3), pp 541-546.

Robinmd (2012). Coping with widowhood. Ageing gracefully. Retrieved from https://robinmd.wordpress.com/ 2012/04/11/coping-with-widowhood/

Smith, K.R., Zick, C.D. \& Duncan, G.J. (1991). Remarriage patterns among recent widows and widowers. Demography, 28(3), pp 361-374.

Smith, S. (1999). Family relationships in later life. Stronger marriage.org

Sutherland, A. (2014). The rise of remarriage [blog post]. Institute for Family Studies. Retrieved from: http://family-studies. org/the-rise-of-remarriage/

Umberson, D., Williams, K., Powers, D.A., Liu, H. \& Needham, B. (2006). You make me sick: Marital quality and health over the life course. Journal of Health and Social Behavior, 47(1), pp 1-16.

Vinick, B. (1978). Remarriage in old age. Aging in a Changing Family Context, 27(4), pp 359-363. 